WS1-5

c-T1NOM0 非小紐胞肺癌に刘する縮小手 術の可能性

红协学: 䀢学部 第一外科

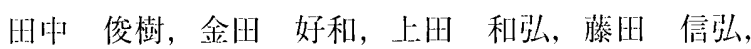
坂野 尚, 优伯 浩一, 須藤 学抔, 松洞 隆久, 林 雅太郎，濱野 公一。

【対㘸と方法】1980年〜2000年に当科で手術が施行された c-T1N0M0症例のうち, 脯葉切除と ND2a 以上のリンパ節 郭清が施行され，術後 2 年以上追跡可能であった 89 例。術 前因子（腫瘍側・腫瘍存在肺葉・腫瘍径・組織型）, 手術 因子 (VATS, 郭清度), p-stageにおける予後を比較した。 【絬果】全症例の 5 生率は $72.6 \%$ であった術前因子では 腫瘍径 $2 \mathrm{~cm}$ が㝋後良好の傾问にあった。手術因子には 差を認めなかった。 p-T1N0M0䬺例は57例あり，正診率 は64\%であった。病期が異なった理由は pT因子：17例， $\mathrm{pN}$ 因子：22例，pM因子：1例であった（重複あり)。pT 因子と $\mathrm{pN}$ 因子を比較すると, $\mathrm{pN}$ 因子陽性涼例の予後が 有意に不良であった。PM陽性例の腫瘍栙は $2 \mathrm{~cm}$ 以上であ った、【考察】 pN 陽性例が 22 例あるため, cN0でも郭清 の省略は危険である。術式・郭清度別による予後には差が なく, c-T1N0M0症例にはVATS lobectomy + ND2aを獎 入すべきである。腫陽径 $2 \mathrm{~cm}$ にはPM陽性例がなく予後 も良好のため, ND2a部清を伴う拡大区域切除は考虑され うる。【絬語】VATS lobectomy + ND2aはc-T1N0M0症 例に対する標準術式となりうる。腫瘍径 大区域切除を考虑できるが, リンパ節郭清の省略は危隃で ある。

\section{MS2-1 当院に扔ける非定型抗酸菌㾟豈外科治療}

国立療養所 西新潟中央病院呼吸器外科

渡辽健宽, 岡佃 英, 濱田利德, 広野達䖉

【日的】非定型抗酸菌症（AM症）に対する治療は1997年 ATSから指針が出され外科治療の有用性が言及された。 当院では病巣が限局した AM症に積極的な外科治療を行 ってきたのでその成績を報告する。【方法】1996年4月か ら2003年1月までの AM症手術例26例を対像。【成績】年 歯令は 15 歳から 75 歳 (平均 50 歳)。男性 13 例, 文性 13 例. 既往症は糖疗病 1 例, 胃切除後 2 例, 肺癌後 1 例, 閉塞性 沛疾患 4 例，脯炎 2 例，䁌炎 2 例，甲状腺疾患 1 例。菌種は M. avium18例, M. intracellulare5例, M. kansasii3 例. 1 例を除いてATSの診断基準を満たした。術前抗菌薬投与 期間は平均 15 ヶ月。術式は葉切 5 例, 葉切 + 区切 1 例, 葉 切 + 部切 1 例, 区切 10 例, 区切 + 部切 1 例, 部切 8 例. VATSは8例。1999年以降は葉切はVATS中葉切除の1例 のみで他はすべて区切以下の切除。合併症は肺瘦 3 例. う ち 1 例が膿脑に移行。術後観察期間は平均 28 ケ。1 例を 除いて再燃なし.【結論】（1）病巣が限局した AM 症に対 して皘極的に手術を行い良好な結果が得られた。（2）種々 の条件を考慮するが，病巣が限局し抗菌薬の效果が得られ ない症例は早期に手術を行うべきである。（3）早期の手術 により切除範囲の縮小やVATSによる恩恵を受けること ができる。

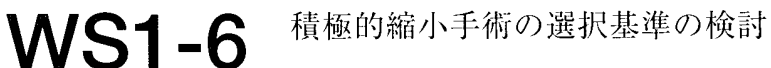

長崎大学 大学院 腫韵外科 (唇崎大学 第一外科), 辰崎大学 医学部 附属病院 病理部

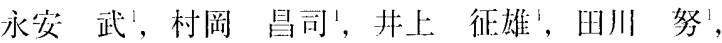

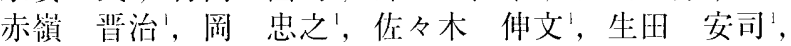
系柳 則昭 ${ }^{\prime}$ ，林 德真吉 ${ }^{2}$

1990 年1月から 2002 年 12 月までに手術を施行した原発性 肺癌 901 例を対象とした。病理病期 I A 期の非小細胞肺癌 は289例で，その内訳は，一肺葉切除 169 例，区域切除 70 例，部分切除 50 例であった。区域切除のうち，治癒を目 的とした積極的縮小手術が 41 例で，術前合併症のための 縮小手術（消極的）が29例であった．各群の5年生存率は， 一肺葉切除術 $84.4 \%$ ，積極的縮小手術 $90.4 \%$ ，消極的縮小 手術 $88.1 \%$ ，部分切除術 $86.6 \%$ といずれも良好であった。 企 901 例中，区域切除を施行した 105 例を腫湟径 $25 \mathrm{~mm}$ 以 下 $(\mathrm{n}=73)$ と $25 \mathrm{~mm}$ 超えるもの $(\mathrm{n}=32)$ の 2 群に分 けた場合，5年生存梁は备々 $89.8 \%$ と $37.5 \%(\mathrm{p}<0.0001)$ であり，腄煬径 $20 \mathrm{~mm}$ 以下 $(\mathrm{n}=57)$ と $20 \mathrm{~mm}$ を超えるも の $(\mathrm{n}=48)$ の2群に分けた場合での5年生存率は各々 $94.4 \%$ と 48.4\% ( $\mathrm{p}<0.0001)$ であった。媑痬径 $25 \mathrm{~mm}$ 以 下の 73 例を年齢が 75 歳以上（ $\mathrm{n}=13)$ と75歳未満 $(\mathrm{n}=$ 60）の 2 群に分けた場合，5年生存率は各々 $90.0 \%$ と

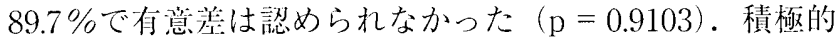

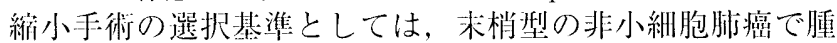
瘍径 $25 \mathrm{~mm}$ 以下の I A 期が爱当であり，高齢者に执いても 辩匛となると考えられた。

\section{WS2-2 非定型抗酸菌症に対する積極的肺切除術}

慶應義熟大学: 呼吸器外科

渡辺 真純, 水下 桂一, 藤本 博行, 木村 吉成, 小山 孝彦, 神山 育男, 後藤 太一郎, 山本学, 泉晹太郎, 江口圭介, 川村雅文, 堀之内 宏久, 小林 絃一.

【日的】肺非定型抗酸菌症（MAC症）に対する肺切除術 を検討し適応と意義を明らかにする。【対象】肺切除術を 施行したMAC症 15 例（男 5，女10，34～77歳，平均 54 歳)。CAMなどを含む多剂併用化療が奏功せず充分な術 後㸬機能が期待される症例を適灾。【結果】全例で赂痰ま たは気管支洗浄液中にM. avium complex を検出。全例が 気管支拡張性または等洞性病変を有し，6２4 ケ月の術前 化療を施行。主な術式（重複あり）は葉切 9, 区切4, 部 切 5 (胸腔鏡 3 例) で複数箇所切除は 8 例 (雨側 4 例)。術 後化療を $3 \sim 17$ ヶ月施行し, $9 \sim 124$ ヶ月全例生存中. 術 後の排菌は 2 例，1例は再化療により停止，1例は巨大空洞 に対して右上切施行，術後対側病巣は縮小しQOLが改善 した。【まとめ】術後合併症なく15例の切除成績は良好で あった。多剂併用化療が奏功せず病桬が限局した症例，特 に気管支搪張性や坒洞性病変が残存し排菌が持続する症例 では積極的な外科治療を考慮すべきである。排菌源となる 巨大空洞性病変の切除後に対側の病巣が改善した症例を経 験した。術後化療を念頭においた両侧多発症例に対する手 術適応の拡大も考虑されうる。 